\title{
Febrile Ulceronecrotic Mucha-Habermann Disease: Treatment with Infliximab and Intravenous Immunoglobulins and Review of the Literature
}

\author{
L. Meziane A. Caudron F. Dhaille M. Jourdan A. Dadban C. Lok G. Chaby \\ Department of Dermatology, Amiens University Medical Centre, South Hospital, and University Picardie Jules Verne, \\ Amiens, France
}

\section{Key Words}

Febrile ulceronecrotic Mucha-Habermann disease - Intravenous immunoglobulins .

Pityriasis lichenoides et varioliformis acuta . Tumor necrosis factor-a inhibitors

\begin{abstract}
Febrile ulceronecrotic Mucha-Habermann disease (FUMHD) is a rare subtype of pityriasis lichenoides et varioliformis acuta, characterized by an acute onset of ulceronecrotic papules, rapidly coalescing into large ulcers with necrotic crusts, associated with high fever and severe systemic symptoms. We report a case of a 65-year-old woman with a resistant form of FUMHD successfully treated with a tumor necrosis factor-a (TNFa) inhibitor (infliximab). After 1 year of treatment, because of the recurrence of lesions and occurrence of severe sepsis, we decided to change the therapeutic procedure by introducing intravenous immunoglobulin witch induced a spectacular improvement. Only few cases of FUMHD treated with intravenous immunoglobulin have been reported to date. In our case, we describe the first utilization of TNFa inhibitors in the treatment of FUMHD: TNFa inhibitors may be useful, particularly in resistant cases. Further reports are required to confirm this potential therapeutic option.
\end{abstract}

Copyright $\odot 2013$ S. Karger AG, Basel

\section{Introduction}

Pityriasis lichenoides et varioliformis acuta (PLEVA) is an uncommon, idiopathic, acquired dermatosis characterized by erythematous, scaly papules often accompanied by hemorrhagic and papulonecrotic lesions. A febrile ulceronecrotic severe variant of PLEVA, called febrile ulceronecrotic Mucha-Habermann disease (FUM$\mathrm{HD}$ ) is more destructive and associated to large coalescent skin necrosis with a rapid progression [1]. 48 cases of PLEVA fulminans have been reported to date in the literature with 9 lethal forms (20\%) (table 1) [1-44]. Oral, genital and conjunctival mucosa can be affected $[2,6,9,12,13]$. Systemic manifestations are present like high fever, myalgia, arthralgia, gastrointestinal and central nervous system symptoms, interstitial pneumonitis, lymphocytic myocarditis, megaloblastic anemia, pancytopenia, and diffuse intravascular coagulation [1, 3, 4, 8, 9, 12]. FUMHD mainly occurs in children and young adults in the second and third decades of life, with a predominance of male and a mean age of 27 years. Children tend to have more favorable outcomes and no deaths have been reported in children. In adults, the mortality was attributed to pulmonary thromboembolism [8, 34], pneumonia [4, 12, 32], cardiac arrest [3], sepsis $[9,18,23,28]$, hy- povolemic shock [27], and massive thrombosis of the superior mesenteric artery [34]. The pathogenesis of PLEVA fulminans has not fully been elucidated, although multiple hypotheses exist. Reported treatments include systemic high-dose corticosteroids, methotrexate, ultraviolet, antibiotics, although efficacy is difficult to determine because of the small number of reported cases.

We describe here the first case of FUMHD treated successfully with infliximab, a tumor necrosis factor- $\alpha$ (TNFa) inhibitor, and with intravenous immunoglobulins (IVIG), and completed with a review of cases reported in the literature.

\section{Case Report}

A 65-year-old woman was admitted to our department for appearance of disseminated ulceronecrotic lesions and fever to $40^{\circ} \mathrm{C}$. Physical examination revealed diffuse erythematous scaly papules with sparse pustules and vesicles that coalesced into confluent ulceronecrotic papules and plaques on the face, the trunk, extremities and flexural areas (fig. 1). The skin lesions involved $90 \%$ of the body surface. Oral, genital and conjunctival mucosae were also involved with large and painful ulcerations (fig. 2).

\section{KARGER}

E-Mail karger@karger.com

www.karger.com/drm (c) 2013 S. Karger AG, Basel

$1018-8665 / 12 / 2254-0344 \$ 38.00 / 0$
Lilia Meziane

Department of Dermatology, Amiens University Medical Centre, South Hospital Avenue René Laënnec

FR-80054 Amiens Cedex 1 (France)

E-Mailliliameziane@yahoo.fr 
Table 1. Literature review

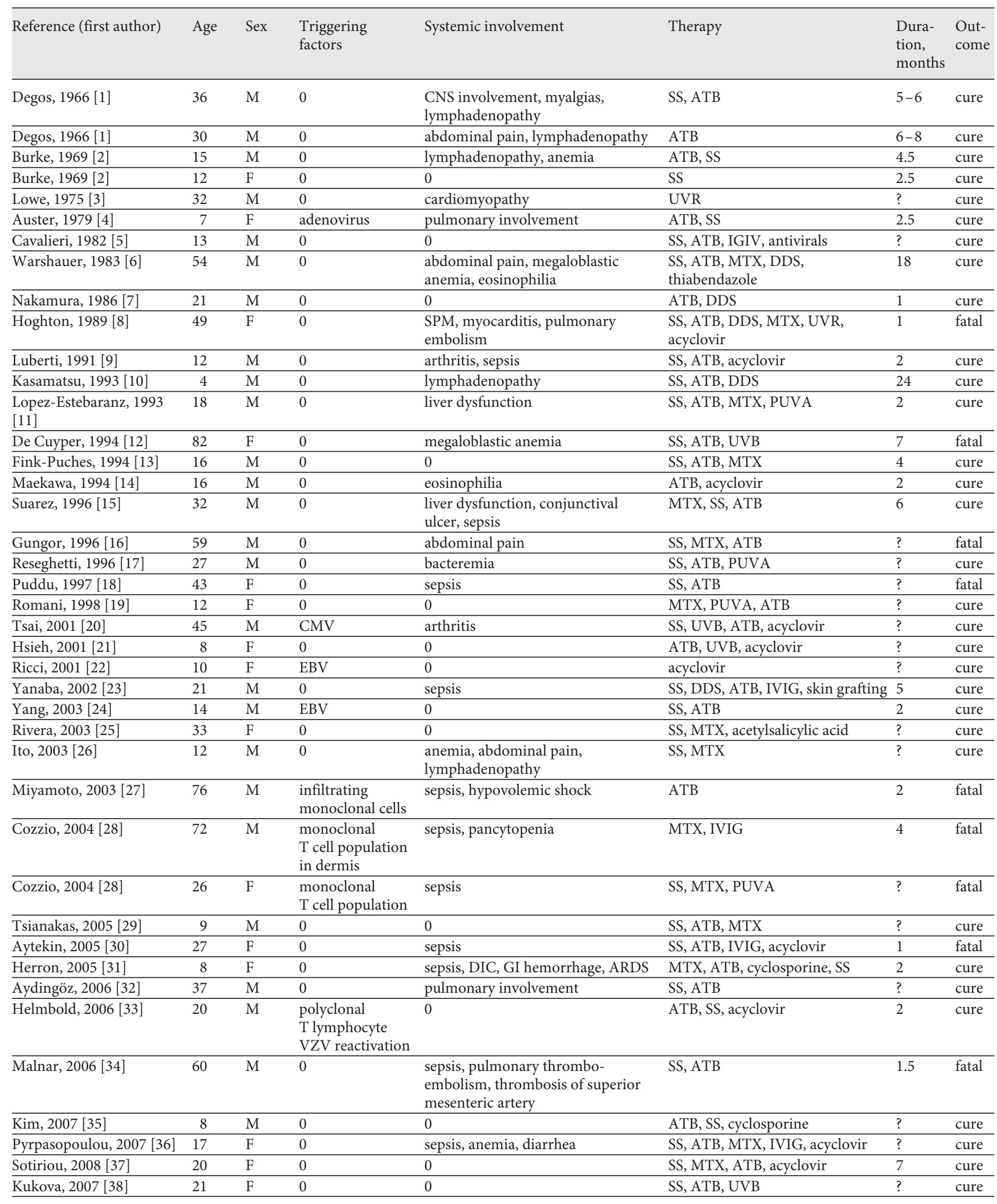

Febrile Ulceronecrotic Mucha-Habermann Disease 
Table 1 (continued)

\begin{tabular}{|c|c|c|c|c|c|c|c|}
\hline Cumming, 2009 [40] & 21 & M & $\begin{array}{l}\text { upper airways } \\
\text { infection }\end{array}$ & 0 & ATB, SS, MTX & 4 & cure \\
\hline Harenberg, 2010 [43] & 30 & $\mathrm{M}$ & 0 & sepsis & SS, ATB & $?$ & cure \\
\hline Kaufman, 2012 [44] & 1.75 & $\mathrm{~F}$ & 0 & laryngeal edema & SS, MTX & 3 & cure \\
\hline Kaufman, 2012 [44] & 1.8 & $\mathrm{~F}$ & 0 & 0 & ATB, acyclovir & $?$ & cure \\
\hline
\end{tabular}

ARDS = Acute respiratory distress syndrome; ATB = antibiotics; CMV = cytomegalovirus; $\mathrm{CNS}=$ central nervous system; DDS $=4,4$-diaminophenylsulphone; DIC = diffuse intravascular coagulation; EBV = Epstein-Barr virus; ECP = extracorporeal photochemotherapy; F = female; GI = gastrointestinal; IVIG = intravenous immunoglobulin; $\mathrm{M}=$ male; $\mathrm{MTX}=$ methotrexate; PUVA = psoralen plus ultraviolet A; $\mathrm{SPM}=$ splenomegaly; $\mathrm{SS}=$ systemic steroids; $\mathrm{UVB}=$ ultraviolet $\mathrm{B} ; \mathrm{UVR}=$ ultraviolet radiation; $\mathrm{VZV}=$ varicella zoster virus.

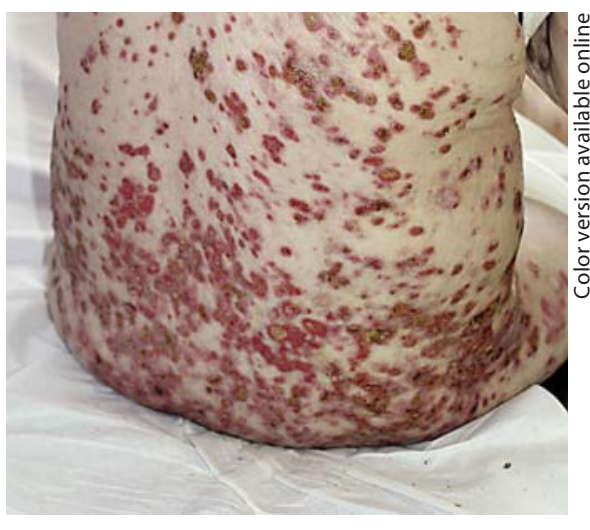

Fig. 1. Diffuse ulceronecrotic lesions on the back, some with central crust.

Routine laboratory tests showed elevated erythrocyte sedimentation rate (120 $\mathrm{mm} / \mathrm{h}$ ), increased level of C-reactive protein $(350 \mathrm{mg} / \mathrm{l})$ and a normochromic-normocytic anemia (10 g/dl). Serology for hepatitis $\mathrm{B}$ virus, hepatitis $\mathrm{C}$ virus, HIV, Epstein-Barr virus (EBV), cytomegalovirus, parvovirus B19, toxoplasma, adenovirus, enterovirus, varicella zoster virus, herpes simplex virus, human herpes virus 6, 7 and 8 were all negative for $\operatorname{IgM}$ and IgG. Sampling microbiological tests of the patient's skin, blood and skin cultures also were negative.

Screening for autoimmunity (antinuclear antibodies, lupus anticoagulant, antibodies to cardiolipin, antineutrophil antibodies), protein electrophoretic, and serum immunoglobulin analysis of peripheral lymphocyte subsets were also normal.

The histopathological exam confirmed the diagnosis of PLEVA and showed acanthosis, focal parakeratosis, with vacuolar and degeneration necrosis of basal layer. Edema of papillary dermis was present, with a perivascular lympho-histiocytic infiltrate and exocytosis. No evidence of vasculitis was present. Immunohistology showed a predominantly CD3+ of lymphocyte infiltrate with an equal number of CD4+ and CD8+ lymphocytes in the epidermal and dermal infiltrate. Staining with CD30 was negative. The research of monoclonal $\mathrm{T}$ cell population in the skin and the blood was negative. The diagnosis of FUMHD was made, based on clinicopathologic correlation.

Our patient was initially treated with oral corticosteroids (prednisone, $60 \mathrm{mg} /$ day), without improvement. Despite the intravenous administration of acyclovir (10 $\mathrm{mg} / \mathrm{kg} /$ day), cutaneous lesions progressed. We started methotrexate (12 mg/week) but it was rapidly discontinued because of the occurrence of a pancytopenia and a renal insufficiency. Because of the severity of the lesions, the resistance to immunosuppressive agents and the progression of PLEVA, TNFa inhibitor was initiated: infliximab $5 \mathrm{mg} / \mathrm{kg}$. The patient received weekly one dose during 4 weeks. The patient became afebrile with a progressive improvement of cutaneous and mucosal lesions. After 4 weeks, injections of infliximab were spaced every 6 weeks with a preservation of complete remission (fig. 3).

One year after the initiation of infliximab, new lesions with painful skin necrosis relapsed. She was septic and hemodynamically unstable. A Candida spice grew from fungal cultures in blood and bronchoalveolar lavage, which required introduction of intravenous antifungal treatment. TNFa inhibitor was stopped because of septic complications and that is why the choice of another anti-TNF was not retained. She was ultimately treated with IVIG at $2 \mathrm{mg} / \mathrm{kg}$ once a week during 2 weeks and then once monthly. An optimal response was obtained with healing of all cutaneous lesions during several months. The administration of IVIG led to significant clinical stabilization, based on reports in the literature, and the previous episodes of successful administration of IVIG. Unfortunately, 8 months after the introduction of IVIG, the patient was transferred to the intensive care unit because of an acute respiratory disease with severe sepsis, and lymphopenia without any skin lesions. Despite intensified systemic therapy, the patient died.

\section{Discussion}

FUMHD involves a sudden, severe flare characterized by coalescent necrotic ulcerations associated with high fever and systemic symptoms, potentially fatal. 


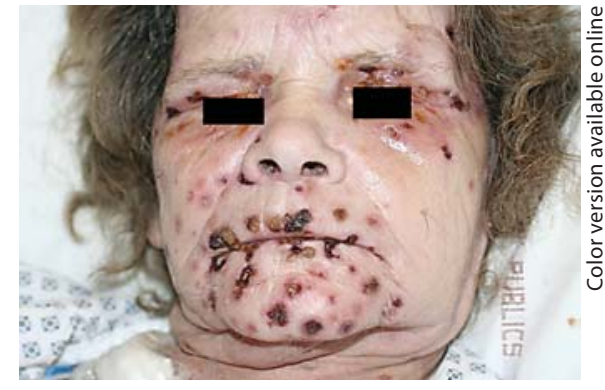

Fig. 2. Necrotic papules and erosions on the face with affected conjunctival mucosae.

FUMHD can occur more frequently in children, adolescents or adults [29]. It exhibits a male predominance (male:female ratio 31:17). The mean age of patients in the reported cases is 27 years (range 1.75$82) ; 33$ of the 48 patients reported were younger than 30 years (table 1).

The reported mortality rate of FUMHD is approximately $20 \%$ (9 of 48 patients). There are no child fatalities; fatal outcome has been seen in adult patients. A comparison between adult and pediatric cases shows a more favorable outcome in children. In fact, until 2004 fatal outcomes were confined to persons older than 40 years. Cozzio et al. [28] and Aytekin et al. [30] reported cases in 2005 of 26- and 27-year-old females with fatal outcomes. Fatal outcomes were linked to pulmonary thromboembolism, sepsis, hypovolemic shock and thrombosis of superior mesenteric artery.

The exact pathogenesis of PLEVA fulminans is unknown. Cutaneous immune response with hypersensitivity to infectious agents was suggested, and several pathogens have been proposed to cause PLEVA such as EBV, adenovirus, cytomegalovirus, parvovirus B19, varicella zoster and HIV-1. Reactivated EBV infection in a patient with PLEVA has been reported by Ricci et al. [22], and also reported by Yang et al. [24]. Auster et al. [4] reported positive culture of adenovirus from the urine in a 7-year-old girl with FUMHD and interstitial pneumonitis. Tsai et al. [20] detected cytomegalovirus infection in the skin biopsy specimen from a 45-yearold male. Recently, Smith and Oliver [39] cultured herpes simplex type 2 from genital and a skin biopsy in 24-year-old male presenting a FUMHD. Finally, FUMHD can belong to the concept of paraviral eruptions proposed by Lipsker and Saurat

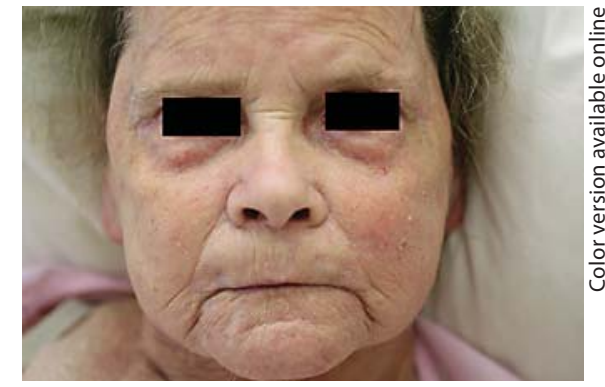

Fig. 3. Healing of cutaneous lesions after 1 month of infliximab treatment.

[45], because viral reactivation is possibly a triggering factor of the disease.

Immunological process might contribute to the pathogenesis of FUMHD. Yanaba et al. [23] observed a predominantly CD8+ lymphocytes infiltrate around the dermis and epidermis which might suggest a cytotoxic attack of lymphocytes to altered epidermal antigens. Some authors have suggested that PLEVA is a benign clonal disorder of activated T cell lymphocytes. Dereure et al. [46] demonstrated that 13 of 20 (65\%) PLEVA biopsy specimens had a dominant $\mathrm{T}$ cell clone. They concluded that PLEVA exists within a spectrum of clonal T cell cutaneous lymphocytic disorders. Weinberg et al. [47] in a retrospective and prospective analysis of PLEVA tissue samples found that 8 of 14 (57\%) specimens demonstrated monoclonal $\mathrm{T}$ cell receptor gene rearrangements. These findings lead to the conclusion that PLEVA is a benign clonal $\mathrm{T}$ cell disorder. Herron et al. [31] reported the presence of CD30+ $\mathrm{T}$ lymphocytes and elevation of soluble IL-2 receptor level in a report of febrile ulceronecrotic PLEVA. Elevated sIL-2R represents systemic $\mathrm{T}$ cell activation, seen in cutaneous $\mathrm{T}$ cell lymphomas. The clonal nature of FUMHD may represent an aggressive entity of cutaneous $\mathrm{T}$ cell lymphomas. Three cases with fatalities had monoclonal disease [27-29]: it has been suggested that $\mathrm{T}$ cell clonality may be related to disease severity.

Several treatment modalities have been described in the literature, but it is difficult to evaluate a defined therapy because of the uncertain etiology, the small number of cases and the combination therapy often employed. Immunosuppressive monotherapy with methotrexate $[6,8,11,13,15$, $19,25,28,29,36,40]$ or cyclosporine $[31$, 35 ] or a combination of one of these with a high dose of glucocorticoids $[6,8,11,13$, $25,28,29,36,41,43]$ has been used in several cases. Antibiotics like erythromycin, acyclovir, ultraviolet phototherapy (PUVA) [11, 19], IVIG [5, 28, 36, 41], photochemotherapy [41], 4,4-diaminodiphenyl sulfone $[7,8,10,23]$, and debridement with skin grafting [23] have also been used to treat FUMHD.

Tsianakas and Hoeger [29] reported abnormally high serum levels of TNFa and suggested that anti-TNFa treatment should be considered and might represent a first line option. In our case, a TNFa inhibitor was administrated after failure of numerous treatments, which induced a rapidly and complete remission. However, the significant loss of response over time of infliximab, the occurrence of severe sepsis in our patient did not lead to use another TNFa inhibitor. In our case, we decided to treat by IVIG proving to be effective in inducing a spectacular improvement and in arresting the appearance of new lesions. IVIG could play a role as adjunctive therapeutic tool in association with TNFa inhibitors or immunosuppressive therapy.

In conclusion, FUMHD is a rare and severe variant of PLEVA that could lead to death in adults. Because of the disease severity, it is important to make the diagnosis as early as possible to start a treatment. We reported the first case of a resistant form of FUMHD, with an initial favorable response to infliximab, and then to IVIG. We suggested that TNFa inhibitors such as IVIG may represent an appropriate therapeutic solution to maintain remission, in severe cases and should be started rapidly.

\section{Disclosure Statement}

The authors declare no conflict of interest.

\section{References}

1 Degos R, Duperrat B, Daniel F: Hyperthermic ulcero-necrotic parapsoriasis. Subacute form of parapsoriasis guttata. Ann Dermatol Syphiligr 1966;93:481-496.

2 Burke DP, Adams RM, Arundell FD: Febrile ulceronecrotic Mucha Habermann's disease. Arch Dermatol 1969;100:200-206.

-3 Lowe NJ: Pityriasis lichenoides et varioliformis acuta and suspected cardiomyopathy. J R Nav Med Serv 1975;61:85-87.
Febrile Ulceronecrotic

Mucha-Habermann Disease
Dermatology 2012;225:344-348 DOI: $10.1159 / 000346245$ 
4 Auster BI, Santa Cruz DJ, Eisen AZ: Febrile ulceronecrotic Mucha-Habermann's disease with interstitial pneumonitis. J Cutan Pathol 1979;6:66-76.

5 Cavalieri R, Didona B, Chinni L: Pitiriasi varioliforme acuta ulcero-necrotica ipertermica. Chron Derm 1982;6:617-623.

6 Warshauer BL, Maloney ME, Dimond RL: Febrile ulceronecrotic Mucha-Habermann's disease. Arch Dermatol 1983;119:597-601.

-7 Nakamura S, Nishihara K, Nadayama K, Hoshi K: Febrile ulceronecrotic MuchaHabermann's disease and its successful therapy with DDS. J Dermatol 1986;13:381-384.

-8 Hoghton MA, Ellis JP, Hayes MJ: Febrile ulceronecrotic Mucha-Habermann disease: a fatality. J R Soc Med 1989;82:500-501.

$\checkmark 9$ Luberti AA, Rabinowitz LG, Ververeli KO: Severe febrile Mucha-Habermann's disease in children: case report and review of the literature. Pediatr Dermatol 1991;8:51-57.

10 Kasamatsu M, Yokota K, Morita A: Febrile ulcero-necrotic Mucha-Habermann's disease. Nishinihon Hifu 1993;55:665-669.

-11 Lopez-Estebaranz JL, Vanaclocha F, Gil R, 26 García B, Inglesias L: Febrile ulceronecrotic Mucha-Habermann disease. J Am Acad Dermatol 1993;29:903-906.

$\checkmark 12$ De Cuyper C, Hindryckx P, Deroo N: Febrile ulceronecrotic pityriasis lichenoides et varioliformis acuta. Dermatology 1994;189 (suppl 2):50-53.

13 Fink-Puches R, Soyer HP, Kerl H: Febrile ulceronecrotic pityriasis lichenoides et varioliformis acuta. J Am Acad Dermatol 1994;30: 261-263.

14 Maekawa Y, Nakamura T, Nogami R: Febrile ulceronecrotic Mucha-Habermann's disease. J Dermatol 1994;21:46-49.

15 Suarez J, López B, Villalba R, Perera A: Febrile ulceronecrotic Mucha-Habermann disease: a case report and review of the literature. Dermatology 1996;192:277-279.

16 Gungor E, Alli N, Artuz F, Lenk N: Febrile ulceronecrotic Mucha-Habermann's disease. Int J Dermatol 1996;35:895-896.

17 Reseghetti A, Parma A, Rozzoni M: Pitiriasi lichenoide e varioliforme acuta febbrile ulceronecrotica. G Ital Dermatol Venereol 1996; 131:55-58.

18 Puddu P, Cianchini G, Colonna L, Girardelli CR, Ferranti G, De Pita O: Febrile ulceronecrotic Mucha-Habermann's disease with fatal outcome. Int J Dermatol 1997;36:691694.

19 Romani J, Puig L, Fernandez-Figueras MT, de Moragas JM: Pityriasis lichenoides in children: clinicopathologic review of $22 \mathrm{pa}-$ tients. Pediatr Dermatol 1998;15:1-6.

20 Tsai KS, Hsieh HJ, Chow KC, Lin TY, Chiang SF, Huang HH: Detection of cytomegalovirus infection in a patient with febrile ulceronecrotic Mucha-Habermann's disease. Int J Dermatol 2001;40:694-698.
21 Hsieh CC, Chiu YK, Ho JC, Huang SC: Febrile ulceronecrotic Mucha-Habermann's disease: report of a case. Dermatol Sinica 2001;19:233-242.

22 Ricci G, Patrizi A, Misciali D, Masi M: Pathological case of the month. Febrile MuchaHaberman disease. Arch Pediatr Adolesc Med 2001;155:195-196.

23 Yanaba K, Ito M, Sasaki H, Inoue M, Nobeyama $\mathrm{Y}$, Yonemoto $\mathrm{H}$, Ishiji $\mathrm{T}$, Tanaka $\mathrm{H}$, Kamide R, Niimura M: A case of febrile ulceronecrotic Mucha-Habermann disease requiring debridement of necrotic skin and epidermal autograft. Br J Dermatol 2002;147: 1249-1253.

24 Yang CC, Lee JY, Chen W: Febrile ulceronecrotic Mucha-Habermann disease with extensive skin necrosis in intertriginous areas. Eur J Dermatol 2003;13:493-496.

25 Rivera R, Ortiz P, Rodriguez-Peralto JL, Vanaclocho F, Iglesias L: Febrile ulceronecrotic pityriasis lichenoides et varioliformis acuta with atypical cells. Int J Dermatol 2003;42:26-28.

26 Ito N, Ohshima A, Hashizume H, Takigawa M, Tokura Y: Febrile ulceronecrotic MuchaHabermann's disease managed with methylprednisolone semipulse and subsequent methotrexate therapies. J Am Acad Dermatol 2003;49:1142-1148.

27 Miyamoto T, Takayama N, Kitada S, Hagari Y, Mihara M: Febrile ulceronecrotic MuchaHabermann disease: a case report and a review of the literature. J Clin Pathol 2003; 56:795-797.

28 Cozzio A, Hafner J, Kempf W, Häffner A, Palmedo G, Michaelis S, Gilliet M, Zimmermann D, Burg G: Febrile ulceronecrotic Mucha-Habermann disease with clonality: a cutaneous T-cell lymphoma entity? J Am Acad Dermatol 2004;51:1014-1017.

29 Tsianakas A, Hoeger PH: Transition of pityriasis lichenoides et varioliformis acuta to febrile ulceronecrotic Mucha-Habermann disease is associated with elevated serum tumour necrosis factor-alpha. Br J Dermatol 2005;152:794-799.

30 Aytekin S, Balci G, Duzgun OY: Febrile ulceronecrotic Mucha-Habermann disease: a case report and a review of the literature. Dermatol Online J 2005;11:31.

31 Herron MD, Bohnsack JF, Vanderhooft SL: Septic, CD-30 positive febrile ulceronecrotic pityriasis lichenoides et varioliformis acuta. Pediatr Dermatol 2005;22:360-365.

32 Aydingöz IE, Kocaayan N, Mansur AT, Pekcan Ş, Arman A: A case of ulceronecrotic Mucha-Habermann disease with pulmonary involvement. Dermatology 2006;212:388390.

33 Helmbold P, Gaisbauer G, Fiedler E, Stücker M, Wolter M, Marsch W: Self-limited variant of febrile ulceronecrotic Mucha-Habermann disease with polyclonal T-cell receptor rearrangement. J Am Acad Dermatol 2006;54: 1113-1115.
34 Malnar T, Milavec-Puretic V, Rados J, Zarkovic K, Dobric I: Febrile ulceronecrotic pityriasis lichenoides et varioliformis acuta with fatal outcome. J Eur Acad Dermatol Venereol 2006;20:303-307.

35 Kim HS, Yu DS, Kim JW: A case of febrile ulceronecrotic Mucha-Habermann's disease successfully treated with oral cyclosporine. J Eur Acad Derm Venereol 2007;21:272-273.

36 Pyrpasopoulou A, Athyros VG, Karagiannis A, Chrysomallis F, Zamboulis C: Intravenous immunoglobulins: a valuable asset in the treatment of a case of septic febrile ulceronecrotic Mucha-Habermann disease. Dermatology 2007;215:164-165.

37 Sotiriou E, Patsatsi A, Tsorova C: Febrile ulceronecrotic Mucha-Habermann disease: a case report and review of the literature. Acta Derm Venereol 2008;88:350-355.

38 Kukova G, Gerber PA, Neumann NJ, BruchGerharz D, Homey B: Febrile ulceronecrotic Mucha-Habermann syndrome. Hautarzt 2007;58:835-836.

-39 Smith JJ, Oliver GF: Febrile ulceronecrotic Mucha-Habermann disease associated with herpes simplex virus type 2. J Am Acad Dermatol 2009;60:149-152.

40 Cumming MM, Salathiel AS, Paino MA, Delort S, Roselino AM: Febrile ulceronecrotic Mucha-Habermann disease with exuberant mucosal involvement: case report. An Bras Dermatol 2009;84:655-658.

41 Marenco F, Fava P, Fierro MT, Quaglino P, Bernengo MG: High-dose immunoglobulins and extracorporeal photochemotherapy in the treatment of febrile ulceronecrotic $\mathrm{Mu}$ cha-Habermann disease. Dermatol Ther 2010;23:419-422.

42 Helbling I, Chalmers RJ, Yates VM: Febrile ulceronecrotic Mucha-Habermann disease: a rare dermatological emergency. Clin Exp Dermatol 2009;34:e1006-e1007.

43 Harenberg PS, Hrabowski M, Ryssel H, Gazyakan E, Germann G, Engel H, Reichenberger MA: Case report febrile ulceronecrotic Mucha-Habermann disease. J Plast Surg 2010;10:433-437.

44 Kaufman WS, McNamara EK, Curtis AR, Kosari P, Jorizzo JL, Krowchuk DP: Febrile ulceronecrotic Mucha-Habermann disease (pityriasis lichenoides et varioliformis acuta fulminans) presenting as Stevens-Johnson syndrome. Pediatr Dermatol 2012;29:135140.

45 Lipsker D, Saurat JH: A new concept: paraviral eruptions. Dermatology 2005;211:309311.

46 Dereure O, Levi E, Kadin ME: T-cell clonality in pityriasis lichenoides et varioliformis acuta: a heteroduplex analysis of 20 cases. Arch Dermatol 2000;136:1483-1486.

47 Weinberg JM, Kristal L, Chooback L, Honig PJ, Kramer EM, Lessin SR: The clonal nature of pityriasis lichenoides. Arch Dermatol 2002;138:1063-1067. 